\title{
Leadership Influence and Job Satisfaction in Islamic Junior High School 2 Teacher Discipline
}

\author{
Budi Hanggari ${ }^{1 *}$, Bukman Lian², Alhadi Yan Putra ${ }^{2}$
}

\author{
${ }^{1}$ SMP Negeri 2 OKU Timur \\ ${ }^{2}$ University of PGRI Palembang \\ *Corresponding author. Email: bsaja71@gmail.com
}

\begin{abstract}
The problem related to teachers' work discipline in Islamic junior high school 2 OKU Timur is the frequent change of leadership in each period so that teachers often experience problems in each leader's patterns or leadership styles. Teachers with high work discipline arrive on time to comply with institutional guidelines because they do not follow the new leadership, so they do not work in a disciplined manner or work as they are. Some teachers have not been disciplined in carrying out their duties because of their good leadership style so that they are disciplined at work. The hypothesis in this study was 1) there is an influence of leadership style on the work discipline of teachers in Islamic junior high school 2 OKU Timur, 2) there is an effect of job satisfaction on the work discipline of teachers in Islamic junior high school 2 OKU Timur, and 3) there is an influence of leadership style and job satisfaction together on the work discipline of teachers in Islamic junior high school 2 OKU Timur. Observation, interviews, and questionnaires do the data collection. The analysis carried out was the correlation analysis of the T-test and the F test. The data analysis results from the questionnaire showed that there was an influence of leadership style on the work discipline of teachers in Islamic junior high school 2 OKU Timur. There is an effect of job satisfaction on teachers' work discipline in Islamic junior high school 2 OKU Timur. There is an influence of leadership style and job satisfaction on teachers' work discipline in Islamic junior high school 2 OKU Timur (significant level 5\%).
\end{abstract}

Keywords: Leadership Style, Job Satisfaction, Work Discipline

\section{INTRODUCTION}

Personal resources are one of the organization's most valuable resources. This is because human resources are one of the internal organizational factors which determines the weaknesses and strengths of organizations. Human resources are one of the internal considerations that play a role in the effectiveness or failure of an organisation to achieve its objectives. The administration of human resources is effective and effective. Schools have a strong teacher performance base. schools. The tasks, obligations and duties of teachers are very important in order to accomplish national education goals, such as educating the nation's life and enhancing its efficiency. It's about the standard of religion and religion, high morality, knowledge and skill, technology and art and the development of a stable and civilized advanced Indonesian society [1].

Education is an attempt to persuade others, individuals, organisations and cultures to do as they intend [2]. Education is an absolute prerequisite for progress. With education, we can follow the wheels of global progress that will make it easier for people who are not competent to follow it. Education is closely related to the icon of actors, supporters, and the educational process. Education is one of the most critical and strategic issues in the growth and improvement of development, including in the provinces, so that in the sense of regional autonomy, the decentralization of education cannot be negotiated in order to increase education quality and human capital [3]. The quality of human capital must be increased first to increase the quality of education. In other words, the quality of education is highly dependent on human resources and the educational process. The quality of human resources in education has a very important influence on the quality of education itself. Quality education will build positive potential among students [4].

Based on the reflection above, education as the spearhead of "human resource production" is an important and very strategic task. In this sense, an educational leader's existence is like a person who has a key role (key position) to achieve the above goals. The 
existence of a leader in education is very necessary, although it is often difficult to choose and get it.

Organizations that succeed in achieving their goals and fulfilling their social responsibilities will rely heavily on their managers (leaders). The presence of the leader/chairman of the institutions is an important part of higher education management [5]. The organisation would probably be able to accomplish its aims if the boss is able to exercise his duties properly. An company requires an efficient leader who can control its members' or subordinates' behaviour. Therefore, an executive leader is recognised whether he has authority and will help his subordinates achieve the organization's predefined objectives. As a leader, the principal is an advocate for the school community, especially teachers, whose priority is to achieve the school's vision, mission and goals [6].

We need leaders in Indonesian millennial education who have a full leadership spirit, namely people who can influence, lead, guide, and some people who have activities to influence others' behavior to follow the wishes of their superiors leaders, to form cooperation. in groups to achieve organizational goals consciously, voluntarily and wholeheartedly, with a distinctive leadership style.

An Islamic school principal must provide a charismatic leadership effect, set an example, mobilize and guide all school stakeholders to achieve the goals to be achieved. The company's success in achieving its objectives depends on its leadership position. Like school leadership, the madrasah leadership model or style would have a major effect on the course and policy of education. By means of leadership, a leader can pass those principles [7]. This makes the principal capable of mobilizing and empowering all the organizational capacity for the growth, evaluation, curriculum development, learning, extracurricular activities and teacher care of different services, procedures and systems. Infrastructure and facilities are designed to provide students and parents with a conducive, clean and comfortable environment in common with the communities, and orderly school in the learning process to achieve school goals [8].

A strong style of leadership would allow the company to accomplish its objectives orderly, comfortably and welcoming. Leadership is an influential, collaborative process which leads to something and shared goals within an organization. According to the importance of leadership in corporate dynamics. In this case, the principal is an education official who depends on the principal's skills and wisdom to run a shady school or institution. A school principal must be able to provide a charismatic leadership effect, be an example, be able to mobilize and guide all school stakeholders to achieve the goals they want to achieve.
A company's success in meeting its targets depends heavily on its leadership position. The principal's management model or personality will play an important role in deciding the course and curriculum policy to be established, as will the school leadership. For this cause, all the talent in the organisation that can be developed and empowered, relating to management of different programmes, procedures, assessments, curriculum creation, classrooms, parasics, teacher care, facilities and equipment, student services and people services, must be mobilized by the Principal. Parents and communities provide a convenient, safe, relaxed environment, ordinary classroom climate for school objectives during the learning process.

Apart from the problems above, Islamic junior high school 2 OKU Timur also experienced problems with teachers because teachers' discipline at Islamic junior high school 2 OKU Timur has not shown optimal results. There are still teachers who often come late. Teachers often arrive late or leave the office during working hours. A teacher at work must be on time and make the best use of his time and participate in institutional activities. In addition, it seems that teachers' availability to work is not well prepared. There are still teachers who work as they are.

In connection with the implementation of duties in the institution, the tasks assigned by management are often not carried out properly or not at all. Therefore, Islamic junior high school 2 OKU Timur continues to strive so that teachers do not often come late or come and fall. The guidance of teachers in carrying out their duties in facilities is very important because in the end, a teacher will certainly become the foundation of these facilities so that they can carry out their duties as expected. Of course, if the teacher carries out simple tasks, this results in unsatisfactory performance results. This can be seen from the implementation of the tasks given to him, which is detrimental to Islamic junior high school 2 OKU Timur. Teachers are the main key to improving the quality and quality of work of an institution. To achieve this, of course, they must be supported by professional and reliable teaching staff in carrying out their duties.

Another problem related to teachers' work discipline at Islamic junior high school 2 OKU Timur is the frequent change of leadership in each period so that teachers often experience problems in their respective leadership patterns or styles. Existing leader. There are teachers with high work discipline who, for example, arrive on time to comply with institutional guidelines because they do not follow the new leadership so they do not work in a disciplined manner or work as they are. Some teachers have not been disciplined in carrying out their duties because of their good leadership style so that they are disciplined at work.

This situation is often experienced by Islamic junior high school 2 OKU Timur with every change of 
leadership. The change of leaders often creates problems because other leaders have different characteristics and characters. Some leaders have authority over teachers, and some are authoritarian. The teacher's work environment is motivated to lead. This often creates conflicts in the institutional structure, which in turn can harm the institution because many teachers do not work in accordance with institutional regulations.

Other factors that can lead to the work discipline of teachers at Islamic junior high school 2 OKU Timur are the low job satisfaction they receive from these facilities, such as: lack of institutional appreciation for their work performance, lack of cooperation between teachers in work, facilities and infrastructure, and a favorable work environment is incomplete or awkward where the teacher feels lazy at the office or doesn't come at all.

Job satisfaction is the feeling conveyed by the teacher or the work he has done. Possibly because the teacher is not satisfied with his work at the facility, because the facility does not pay attention to work and work performance, so he is lazy to carry out his duties and does not comply with existing provisions.

From this description, the authors are interested in seeing how far the relationship between leadership style and job satisfaction obtained by teachers worked at Islamic junior high school 2 OKU Timur with teacher work discipline in carrying out their duties, as well as how the current teacher work discipline with leadership styles and job satisfaction. they got. So that the author wants to examine the research about "Leadership Influence and Job Satisfaction In Islamic Junior High School 2 Teacher Discipline".

\section{METHODS}

This investigation was carried out in Islamic Junior High School 2 in OKU Timur. In this research, the authors have used quantitative data, i.e. data collection testing, description and findings appearance, which requires the use of numbers. Quantitative research is a kind of science, the parameters of which are formal, designed and precisely defined from the outset.

According to Sugiyono [9], the population is "a generalization area consisting of objects or subjects with certain quantities and characteristics that researchers expected to study and then draw conclusions." The population that became the object of this study were all teachers at Islamic junior high school 2 OKU Timur, totaling 54 teachers. The sample is part or representative of the population under study [10]. It is best to take the whole study in order to decide the sample dimensions if the topic is less than 100. If the subject is larger, 20-25 percent may be taken [11]. Based on this view, 54 individuals were considered to be the entire population in this survey. In addition, 15 people from another location, namely Islamic Junior High School 4 OKU Timur, were tested for the research instrument.

The techniques of data collection are a vital phase in the research as the primary objective of the research is to obtain information. The researcher cannot receive data that satisfies the existing data norms without understanding the technology for data collection [9].

\section{RESULTS AND DISCUSSION}

Hypothesis testing is done by using correlation techniques, while the correlation techniques used are statistical analysis of correlation and determination, regression coefficient (T-test), and association correlation coefficient ( $\mathrm{F}$ test), which were carried out using SPSS version 21.

\section{Hypothesis Testing of Principal Leadership Style (X1) on Work Discipline (Y)}

\begin{tabular}{|c|c|c|c|c|c|c|}
\hline \multicolumn{7}{|c|}{$\begin{array}{l}\text { Table 1. Significance of the influence of Leadership } \\
\text { Style to Work Discipline }\end{array}$} \\
\hline \multirow{2}{*}{\multicolumn{2}{|c|}{ Model }} & \multicolumn{2}{|c|}{$\begin{array}{l}\text { Unstandardized } \\
\text { Coefficients }\end{array}$} & \multirow{2}{*}{$\begin{array}{c}\text { Standardized } \\
\text { Coefficients }\end{array}$} & \multirow[t]{2}{*}{$\mathrm{t}$} & \multirow[t]{2}{*}{ Sig. } \\
\hline & & B & $\begin{array}{l}\text { Std. } \\
\text { Error }\end{array}$ & & & \\
\hline \multirow[t]{2}{*}{1} & (Constant) & 3.709 & 6.674 & & 0.556 & 0.581 \\
\hline & $\begin{array}{l}\text { Principal } \\
\text { Leadership } \\
\text { Style }\end{array}$ & 0.776 & 0.082 & 0.797 & 9.503 & 0.000 \\
\hline & Dependent & riable: & Vork I & cipline & & \\
\hline
\end{tabular}

From the table above, the $\mathrm{t}$ value is 9.503 with a sig level of 0.000 . Because the sig value is less than 0.05 , the hypothesis says there is an influence of leadership style on the work discipline of Islamic junior high school 2 OKU Timur teachers. This means that the leadership style affects the teachers' work discipline at Islamic junior high school 2 OKU Timur. The interpretation of the correlation coefficient above is. 


\section{Hypothesis Testing of Job Satisfaction $\left(\mathrm{X}_{2}\right)$ on Work Discipline (Y).}

\begin{tabular}{|c|c|c|c|c|c|}
\hline \multirow{3}{*}{ Model } & \multicolumn{5}{|c|}{$\begin{array}{l}\text { Table 2. Significance of the influence of Job } \\
\text { Satisfaction to Work Discipline }\end{array}$} \\
\hline & \multicolumn{2}{|c|}{$\begin{array}{l}\text { Unstandardized } \\
\text { Coefficients }\end{array}$} & \multirow{2}{*}{$\begin{array}{c}\text { Standardized } \\
\text { Coefficients }\end{array}$} & \multirow[t]{2}{*}{$\mathrm{t}$} & \multirow[t]{2}{*}{ Sig. } \\
\hline & B & $\begin{array}{l}\text { Std. } \\
\text { Error }\end{array}$ & & & \\
\hline \multirow{2}{*}{$\begin{array}{ll}1 & \text { (Constant) } \\
\text { Job } \\
\text { Satisfaction }\end{array}$} & 5.709 & 5.884 & & 0.970 & 0.336 \\
\hline & 0.751 & 0.072 & 0.823 & 10.440 & 0.000 \\
\hline a. Dependent V & iable: & ork D & ipline & & \\
\hline
\end{tabular}

From the table above, the $\mathrm{t}$ value is 10,440 with a sig level of 0,000 . Because the sig value is less than 0.05 , the hypothesis that there is an effect of Job Satisfaction on the work discipline of Islamic junior high school 2 OKU Timur teachers is accepted. This means that Job
Satisfaction affects teachers' work discipline at Islamic junior high school 2 OKU Timur.

3. Hypothesis Testing Leadership Style $\left(X_{1}\right)$ and Job Satisfaction $\left(\mathrm{X}_{2}\right)$ on Work Discipline (Y)

Table 3. The results of multiple regression Leadership Style and Job Satisfaction to Work Discipline

\begin{tabular}{|c|c|c|c|c|c|}
\hline Model & $\begin{array}{l}\text { Sum of } \\
\text { Squares }\end{array}$ & df & $\begin{array}{c}\text { Mean } \\
\text { Square }\end{array}$ & $\mathrm{F}$ & Sig. \\
\hline $\begin{array}{ll}1 & \text { Regression }\end{array}$ & 1105.439 & 2 & 552.720 & 56.429 & $.000^{\mathrm{b}}$ \\
\hline Residual & 499.542 & 51 & 9.795 & & \\
\hline Total & 1604.981 & 53 & & & \\
\hline
\end{tabular}

a. Dependent Variable: Work Discipline

b. Predictors: (Constant), Leadership Style, Job Satisfaction

The F value is 56,429 from the above table and the sig amount is 0,000 . The sig value being lower than 0.05 means that the type of leadership and job satisfaction in Islamic junior high school is influenced by the professional work discipline. 2 all right 2 Timur shall be approved.

\section{CONCLUSION}

In the previous part, the outcome of the investigation and debate took place. It has been performed by descriptive analyzes and inferential statistical analyses. The results of this analysis are as follows: Leadership style in the Islamic Junior High School 2 OKU Timur has an effect on teachers' job discipline. Job satisfaction has an effect on the job discipline of teachers at Islamic Juniors 2 OKU Timur. In Islamic Junior High School 2 OKU Timur together, leadership and job satisfaction impact the working discipline of students.

Researchers are able to follow up further on this study's results by developing independent variables that can improve work discipline at Islamic junior high school
2 OKU Timur. This needs to be done because there are still other factors that have an influence on the work discipline of the teacher besides the leadership style and job satisfaction because the leadership style determines only $68.9 \%$ of the teacher's work discipline and job satisfaction, meaning $31.1 \%$ is determined by factors outside the leadership style and satisfaction. Work such as supervision, work professionalism, and others.

\section{REFERENCES}

[1] Thomson. (2002). Manajemen Sumber daya Manusia. Jakarta: Salemba Empat.

[2] Murkatik, K., Harapan, E., \& Wardiah, D. (2020). The Influence of Professional and Pedagogic Competence on Teacher's Performance. Journal of Social Work and Science Education, 1(1), 58-69. Retrieved

from https://ejournal.karinosseff.org/index.php/jswse/art icle/view/10 
[3] Rohma, S., Harapan, E., \& Wardiah, D. (2020). The Influence of School-Based Management and Teacher's Professionalism toward Teacher's Performance. Journal of Social Work and Science Education, 1(1), 13-23. Retrieved from https://ejournal.karinosseff.org/index.php/jswse/art icle/view/6

[4] Sarbini., Kristiawan, M., \& Wardiah, D. (2020). Supervisor's Performance for the Quality of Education. International Journal of Progressive Sciences and Technologies (IJPSAT), 20(1), 255 262.

[5] Mukhtar, Yamin, M., \& Nurzen, S. S. (2020). The Influence of Academic Culture, Management Knowledge and Interpersonal Communication on Decision Making by the Head of Private Islamic Colleges in Jambi Province. International Journal of Progressive Sciences and Technologies (IJPSAT) Vol. 23 No. 2 November 2020, pp. 09-19.

[6] Suratman, S., Arafat, Y., \& Eddy, S. (2020). The Influence of Principal's Leadership and Teacher's Competence toward Teacher's Performance in Indonesia. Journal of Social Work and Science Education, 1(2), 96-104. Retrieved from https://ejournal.karinosseff.org/index.php/jswse/art icle/view/32

[7] Ruslan, Lian, B., \& Fitria, H. (2020). The Influence of Principal's Situational Leadership and Teacher's Professionalism on Teacher's Performance. International Journal of Progressive Sciences and Technologies (IJPSAT), 20(1). Retrieved from https://ijpsat.ijsht-

journals.org/index.php/ijpsat/article/view/1733

[8] Oslan. (2015). Pengaruh Disiplin Kerja, Gaya Kepemimpinan Dan Kepuasan Kerja Terhadap Kinerja Guru Di SMA Negeri 7 Palu. e-Jurnal Katalogis, 3(12), 14-21.

[9] Sugiyono. (2017). Statistika Untuk Penelitian. Bandung: Alfabeta.

[10] Arikunto, S. (2013). Metode Penelitian dan Statistika. Jakarta: Dunia Pustaka Jaya.

[11] Arikunto, S. (2006). Prosedur Penelitian Suatu Pendekatan Praktik. Jakarta. Rineka Cipta. 